\title{
Sensory Characteristics of Dehydrated Coriander Leaves under Greenhouse Type Solar Dryer and its Qualitative Evaluation during Storage
}

\author{
Sanjay Kumar Singh ${ }^{1 *}$, Samsher ${ }^{2}$, B. R. Singh², R. S. Sengar ${ }^{2}$ and Pankaj Kumar \\ ${ }^{1}$ ICAR - Indian Grassland and Fodder Research Institute, Jhansi, India \\ ${ }^{2}$ S. V. P. University of Agric. \& Tech., Meerut, U. P., India \\ *Corresponding author
}

\section{A B S T R A C T}

\begin{tabular}{|l|}
\hline Ke y w o r d s \\
Greenhouse, \\
Coriander, \\
Dehydration, \\
Sensory \\
characteristics, \\
Storage
\end{tabular}

\section{Introduction}

In India, coriander plays key role in national economy because about $80 \%$ of world supply of coriander is produced in India. Coriander is used as a valuable spice for its exotic flavour, stimulant and carminative properties while fluid - extract (and oil) is used medicinally as antispasmodic, for rheumatism and as a tonic. It is valued for its fruits called coriander seeds
Experiment was conducted to evaluate the availability of coriander leaves in off season by dehydration under greenhouse type solar dryer as compared to open sun (control) at three levels each of pretreatments (dipping in a solution containing $0.1 \% \mathrm{MgCl}_{2}+0.1 \%$ $\mathrm{NaHCO}_{3}+2 \% \mathrm{KMS}$ in distilled water; blanching in boiling water containing $0.5 \%$ sodium metabisulphite, and untreated i.e. control) and loading densities $\left(2.0,2.5\right.$ and $\left.3.0 \mathrm{~kg} / \mathrm{m}^{2}\right)$. Sensory evaluation of dehydrated coriander leaves and changes in quality characteristics viz. chlorophyll content, ascorbic acid and rehydration ratio were studied during four months storage. The maximum value of sensory score of overall acceptability (8.5) for dehydrated coriander was obtained for chemical treated coriander leaves in the solution of $0.1 \% \mathrm{MgCl}_{2}+0.1 \% \mathrm{NaHCO}_{3}+2 \% \mathrm{KMS}$ and with $2.5 \mathrm{~kg} / \mathrm{m}^{2}$ loading density under greenhouse type solar dryer, while minimum score (6.0) were found for open sun drying with boiling water treated samples at $2.5 \mathrm{~kg} / \mathrm{m}^{2}$ loading density. Four months storage study of dehydrated coriander leaves revealed losses of $18.9 \%$ in chlorophyll content, $27.22 \%$ in ascorbic acid and $2.84 \%$ in rehydration ratio for the dehydrated product under greenhouse type solar dryer, as compared to the losses of $18.6 \%$ in chlorophyll content, $29.0 \%$ in ascorbic acid and $1.91 \%$ in rehydration ratio under open sun drying. 
The entire plant when young is used in preparing chutneys, salad and sauces and the leaves are also used for flavouring and garnishing curies and soups. These can also be used for flavouring pasty, cookies, buns, cakes and tobacco products. The coriander leaves is also used as breath fresheners too and we feel sweeter breath as green plant pigment chlorophyll is a powerful breath freshener. The degree of greenness is important in determining the final quality of thermally processed green vegetables which gets their colour from chlorophyll pigments. Chlorophyll a appears blue - green and thermally less stable than chlorophyll b which appears yellow - green (Tan and Francis, 1962). For green vegetables, blanching and pretreatment prior to drying can aid the chlorophyll retention during drying operation. Several studies have been carried out to investigate the effect of pretreatment and hot air temperature on quality of processed vegetables (Kaur et al., 2006). In India, fresh coriander leaves is abundantly available during winter from December to March but has very short shelf life even under refrigerated conditions. This leads to a market scarcity and a sharp rise in price during lean period. Fresh coriander leaves are perishable in nature and require immediate processing or preservation. During peak period, a considerable amount of the produce is wasted due to lack of proper post harvest processing technique. Therefore, there is a need for dehydrated leafy vegetables so that their availability time can be extended.

The proper drying techniques are the most important aspect of leafy vegetable preservation. The use of solar dryer helps not only to reduce the losses and improves the quality of product but also helps in conserving the conventional energy sources. The solar energy which is available in abundance in India is most commonly used for this purpose. The greenhouse type solar dryer is based on greenhouse effect which traps the solar energy in the form of thermal heat within the cover, reduces the convective heat loss and resulting in a subsequent increase in temperature. These can be exploited in summer and during sunny days in any season for drying agricultural products and may become a more convenient alternative. Although many solar dryers have been developed, greenhouse type dryers have great potential in India and may be constructed at farm level (production point) which minimizes the transport cost and losses during transport. Singh et al., 2017 developed solar dryer for dehydration of fodder crops and observed $39.8{ }^{0} \mathrm{C}$ temperature under the dryer when the ambient temperature was $29.5{ }^{0} \mathrm{C}$. With all this basic information, efforts were made to enhance the availability of coriander leaves in off season by dehydration under greenhouse type solar dryer as compared to open sun with the study of sensory characteristics of dehydrated coriander leaves and changes in quality characteristics during storage.

\section{Materials and Methods}

Coriander (cv. Pant Haritma) was produced under greenhouse at Horticultural Research Centre of SVP University of Agri. \& Tech., Meerut. Coriander leaves were harvested from greenhouse one day before the start of the drying experiment. It was washed thoroughly in fresh water so as to remove roots and stem and leaves and soft stem were separated from the rest parts. A greenhouse type solar dryer developed at Horticultural Research Centre of SVP University of Agri. $\&$ Tech., Meerut, Uttar Pradesh was used for the dehydration of coriander. The greenhouse type solar dryer consists of drying chamber and covered with 200 micron UV stabilized polyethylene sheet, cement concrete floor insulated with glass wool and covered with black painted iron sheet, insect proof inlet 
opening for dry air, outlet opening on north wall for releasing humid air, and black shade net $(70 \%)$ below the top glazing material. Because of the greenhouse effect, there is heat accumulation inside the dryer after transmission of solar radiation through the plastics sheet. This thermal energy was utilized to dehydrate coriander leaves under the developed greenhouse type solar dryer.

Dehydration of washed coriander samples was carried under greenhouse type solar dryer (GSD) and open sun drying (OSD) at three levels each of pretreatments (T1: dipping in the solution of $0.1 \% \mathrm{MgCl}_{2}+0.1 \% \mathrm{NaHCO}_{3}$ $+2 \% \mathrm{KMS}$ for $15 \mathrm{~min}$; T2: blanching in boiling water containing $0.5 \%$ sodium metabisulphite for $2 \mathrm{~min}$ and T3: control i.e. untreated) and loading densities (2.0, 2.5 and $3.0 \mathrm{~kg} / \mathrm{m}^{2}$ ). Pretreated samples with respective loading density (weight of fresh leaves per unit area of drying tray) were exposed for dehydration under greenhouse type solar dryer and in open sun. The drying started at 10:00 am and stopped at about 5:00 pm, afterward, the samples were collected and kept in air tight plastics covers to induce uniform moisture distribution in coriander leaves. They were spread again on the trays in the next morning and the process was repeated until the final dehydration of leaves reached. Environmental temperature and relative humidity under the greenhouse dryer and in open sun were measured using $\mathrm{RH} /$ Temperature meter. The sensory characteristics of dehydrated coriander leaves obtained from greenhouse type solar dryer as well as open sun were evaluated during storage.

\section{Sensory evaluation}

Sensory evaluation was carried out of dehydrated coriander leaves and rehydrated coriander leaves by a ten-member panel of different age group and different food habits for surface appearance, colour, taste of rehydrated sample, flavour and overall acceptability. The sensory evaluation was done on 9 - point hedonic scale recommended by Indian Standard (Anon, 1971). The average score of all the ten panelists were computed to optimize the variables/parameters.

\section{Storage Study}

Storage of best three samples as obtained from sensory evaluation were carried out for determination of changes in quality characteristics in terms of chlorophyll content, ascorbic acid and rehydration characteristics at $0,15,30,45,60,75,90,105$ and 120 days of storage at room temperature. The chlorophyll content, vitamin $\mathrm{C}$, and rehydration characteristics of dehydrated coriander leaves were evaluated as per following methods:

\section{Rehydration characteristics}

The rehydration ratio (RR) and coefficient of rehydration (CR) were computed using the following equation (Ranganna, 1986).

RR

$$
=\frac{\mathrm{W}_{2}}{\mathrm{~W}_{1}}
$$

CR

$$
=\frac{\mathrm{W}_{2} \times\left(100-\mathrm{M}_{\mathrm{I}}\right)}{\left(\mathrm{W}_{1}-\mathrm{M}_{\mathrm{F}}\right) \times 100}
$$

Where,

$\mathrm{W}_{1}=$ Weight of the dehydrated coriander leaves taken for rehydration, $g$

$\mathrm{W}_{2}=$ Drained weight of the rehydrated coriander leaves, $g$

$\mathrm{M}_{\mathrm{F}}=$ Amount of moisture present in the dried sample taken for rehydration, $g$

$\mathrm{M}_{\mathrm{I}}=$ Moisture content of sample before drying, $\%$. 


\section{Chlorophyll content}

Total chlorophyll was measured following the method describe by Arnon (1949). Chlorophyll pigment was extracted from $1 \mathrm{~g}$ dry matter in $80 \%$ acetone and was determined using spectral analysis (Beckman) by measuring the absorbance at 663 and 645 $\mathrm{nm}$. The following equation was used to determine the Chlorophyll content.

Total chlorophyll $(\mathrm{mg} / \mathrm{g}$ tissue $)=\left[20.2\left(\mathrm{~A}_{645}\right)\right.$ $\left.+8.02\left(\mathrm{~A}_{663}\right)\right] \times \frac{\mathrm{V}}{1000 \times \mathrm{W}}$

Where,

A = Absorbance at specific wavelengths,

$\mathrm{V}=$ Final volume of chlorophyll extract in 80

$\%$ acetone,

$\mathrm{W}=$ Fresh weight of the tissue extracted

\section{Ascorbic acid content}

The ascorbic acid content was estimated by 2 , 6 - dichlorophenol indophenol dye visual titration method (Ranganna, 1986). The dye is blue in alkaline solution and red in acid solution. The dye colour is reduced by ascorbic acid to a colourless form. Five $\mathrm{ml}$ of $\mathrm{HPO}_{3}$ was added to $5 \mathrm{ml}$ standard ascorbic acid. Micro burette was filled with dye and titrated with dye solution to pink colour which persist at least $15 \mathrm{sec}$. Dye factor i.e. $\mathrm{mg}$ of ascorbic acid per $\mathrm{ml}$ of the dye, was calculated using the following formula.

Dye factor $=\frac{\text { O.S }}{\text { titre }}$

Sample of $2 \mathrm{~g}$ blended with $3 \% \mathrm{HPO}_{3}$ and volume was made to $20 \mathrm{ml}$ with $\mathrm{HPO}_{3}$ and filtered. An aliquot $(2 \mathrm{ml})$ of the $\mathrm{HPO}_{3}$ extract of sample was taken and titrated against the standard dye to a pink colour end point which should persist for at least $15 \mathrm{sec}$. Titration was rapidly carried out and a preliminary determination was made of the titre. The experiment was repeated for getting accurate results and the value of ascorbic acid was calculated using following equation.

$$
\begin{aligned}
& \text { Ascorbic acid } \quad(\mathrm{mg} / 100 \quad \mathrm{~g}) \\
& = \\
& \text { Titre value } \times \text { Dy efactor } \times \text { Vol. made up } \times 100
\end{aligned}
$$

Extract taken for estimation $\times$ Wt.of sampletaken

\section{Statistical Analysis}

The experimental data for sensory characteristics of coriander leaves and its storage behaviour was statistically and graphically analyzed with the help of spread sheet (EXCEL) and CURVE EXPERT 1.3 software packages on personal computer.

\section{Results and Discussion}

Experiments were conducted to evaluate the sensory characteristics of dehydrated coriander leaves after dehydration in developed greenhouse type solar dryer and in open sun with selected levels of loading density and pretreatments. The average temperatures under greenhouse type solar dryer and in open sun were $42{ }^{\circ} \mathrm{C}$ and $29{ }^{\circ} \mathrm{C}$ respectively, during experimentation. The results obtained are discussed below.

\section{Effect of drying conditions on sensory characteristics}

The mean sensory ratings for colour, appearance, taste of the rehydrated sample, flavour and overall acceptability have been given in Table 1. The mean scores for colour varied from 6 to 9 . The maximum value corresponds to the processing condition of greenhouse type solar dryer (temperature of $42{ }^{\circ} \mathrm{C}$ ) for chemically treated samples and 2.5 $\mathrm{kg} / \mathrm{m}^{2}$ loading density while corresponding 
conditions for minimum score (6) was for boiling water treated samples and $3.0 \mathrm{~kg} / \mathrm{m}^{2}$ loading density under open sun drying (29 $\left.{ }^{\circ} \mathrm{C}\right)$. It was observed that under greenhouse type solar dryer having the provision of shade net, the chlorophyll content could not decreased much as compared to open sun drying. Also pretreatments and drying methods have influence on chlorophyll content, which is mainly responsible for the degree of greenness of coriander leaves. Boiling water blanched samples had lowest score of greenish colour. Influence of loading density on colour was less. Pande et al., (2000) found that solar dried coriander retain their flavour and exhibit only minor change in colour and appearance. Therefore, these observations are in line with those reported earlier. In general, total chlorophyll decreased for the dehydrated samples blanched under boiling water. The colour retention in chemically treated samples might have been due to KMS treatment with faster drying under GSD. Higher chlorophyll content for chemically treated samples may be because of KMS treatment. The lower chlorophyll content under OSD was due to inactivation of chlorophyllase enzyme which may be responsible for degradation of chlorophyll. The mean scores for appearance varied from 6 to 8 .

The higher score corresponds to the drying methods of GSD and OSD for chemical treated and untreated samples having a mean score of 8 , while minimum score of 6 was for boiling water treated samples under OSD and GSD condition. In general, it was observed that at greenhouse drying methods, the appearance of rehydrated coriander leaves was good.

The mean scores for the taste varied from 6 to 9. The maximum value corresponds to the greenhouse drying methods of chemically treated samples $\left(42^{\circ} \mathrm{C}\right)$ with $2.5 \mathrm{~kg} / \mathrm{m}^{2}$ loading density having a mean score of 9, while corresponding conditions for minimum score were for boiling water treated and untreated samples under open sun drying. It was observed that under greenhouse type solar drying and for chemically treated samples, taste was better than other samples. Effect of treatment on taste was significant while insignificant effect was observed with drying method and loading density. The mean scores for the flavour varied from 5 to 8 . The maximum value corresponds to the greenhouse drying conditions of $42{ }^{0} \mathrm{C}$, chemically treated sample at $2.5 \mathrm{~kg} / \mathrm{m}^{2}$ loading density having a score of 8 , while under sun drying, corresponding conditions for minimum score (5) were for boiling water treated and untreated samples. It was observed that under GSD and at medium loading density, flavour was good and a declined score was observed for others.

The mean scores of overall acceptability varied from 6 to 8.5. The maximum value (8.5) corresponds to the processing condition of GSD, chemically treated sample at 2.5 $\mathrm{kg} / \mathrm{m}^{2}$ loading density, while minimum score were found for OSD, boiling water treated sample at $2.5 \mathrm{~kg} / \mathrm{m}^{2}$ loading density. It was observed that under GSD, colour was acceptable, and in this system flavour and appearance was also good and it was decreased under OSD.

\section{Storage behavior of dehydrated coriander leaves}

From sensory evaluation of all the samples, three best samples were chosen and stored in desiccators at room temperature $\left(30-40{ }^{\circ} \mathrm{C}\right)$ in polythene packing and change in quality characteristics viz. chlorophyll content, ascorbic acid and rehydration ratio were studied for the duration of 120 days at an interval of 15 days. The samples choosen were as follows: 
(i) $\mathrm{G} 1: 2.5 \mathrm{~kg} / \mathrm{m}^{2}$ loading density, chemical treated sample under GSD;

(ii) G2: $2.5 \mathrm{~kg} / \mathrm{m}^{2}$ loading density, untreated sample under GSD;

(iii) $\mathrm{G} 3: \quad 2.5 \mathrm{~kg} / \mathrm{m}^{2}$ loading density, chemically treated sample under OSD

The change in chlorophyll content, ascorbic acid and rehydration ratio are presented in Table 2 and their graphical presentation are shown in Fig. 1, 2, and 3 respectively.

Fig. 1 showed the data and variation on chlorophyll content (mg/g tissue) at $0,15,30$, $45,60,75,90,105$ and 120 days of storage. It was observed that in $\mathrm{G} 1$, a total reduction of
$18.90 \%$ from $1.439 \mathrm{mg} / \mathrm{g}$ tissue (0 day) to $1.167 \mathrm{mg} / \mathrm{g}$ tissue (120 days); in G2, a total reduction of $19.0 \%$ from $1.431 \mathrm{mg} / \mathrm{g}$ tissue $(0$ day) to $1.157 \mathrm{mg} / \mathrm{g}$ tissue (120 days) and in $\mathrm{G} 3$, a total reduction of $18.6 \%$ from 1.159 $\mathrm{mg} / \mathrm{g}$ tissue (0 day) to $0.943 \mathrm{mg} / \mathrm{g}$ tissue (120 days) was found. The decrease in chlorophyll content during storage is due to the oxidation of chlorophyll pigments. Similar results had been reported by Ahmed et al., (2004) for coriander leaf paste. At the start of storage, maximum chlorophyll content $(1.439 \mathrm{mg} / \mathrm{g}$ tissue) was found for the samples dehydrated under GSD $\left(42{ }^{0} \mathrm{C}\right)$ and minimum (1.159 $\mathrm{mg} / \mathrm{g}$ tissue) was for the sample dehydrated under OSD $\left(29{ }^{0} \mathrm{C}\right)$. The loss in chlorophyll content was observed to be more under OSD condition.

Table.1 Mean sensory ratings for colour, appearance, taste of the rehydrated sample, flavour and overall acceptability

\begin{tabular}{|c|c|c|c|c|c|c|c|}
\hline $\begin{array}{c}\text { Drying } \\
\text { methods }\end{array}$ & $\begin{array}{l}\text { Loading density } \\
\left(\mathrm{kg} / \mathrm{m}^{2}\right)\end{array}$ & $\begin{array}{c}\text { Treat } \\
\text {-ments }\end{array}$ & colour & $\begin{array}{l}\text { Appear } \\
\text { ance }\end{array}$ & Taste & flavour & $\begin{array}{c}\text { Over all } \\
\text { Acceptability }\end{array}$ \\
\hline \multirow[t]{9}{*}{ GSD } & \multirow[t]{3}{*}{2.0} & CT & 8 & 7 & 7 & 6 & 7 \\
\hline & & BW & 8 & 6 & 6 & 5 & 6.5 \\
\hline & & UT & 8 & 7 & 6 & 5 & 6.5 \\
\hline & \multirow[t]{3}{*}{2.5} & CT & 9 & 8 & 9 & 8 & 8.5 \\
\hline & & BW & 7 & 6 & 7 & 7 & 6.25 \\
\hline & & UT & 8 & 8 & 8 & 7 & 7.75 \\
\hline & \multirow[t]{3}{*}{3.0} & CT & 8 & 7 & 7 & 7 & 7.25 \\
\hline & & BW & 7 & 6 & 6 & 6 & 6.25 \\
\hline & & UT & 8 & 8 & 7 & 6 & 7.25 \\
\hline \multirow[t]{9}{*}{ OSD } & \multirow[t]{3}{*}{2.0} & CT & 7 & 7 & 7 & 6 & 6.75 \\
\hline & & BW & 7 & 7 & 6 & 5 & 6.25 \\
\hline & & UT & 8 & 7 & 6 & 5 & 6.5 \\
\hline & \multirow[t]{3}{*}{2.5} & CT & 8 & 8 & 7 & 7 & 7.5 \\
\hline & & BW & 7 & 6 & 6 & 5 & 6 \\
\hline & & UT & 7 & 7 & 7 & 5 & 6.5 \\
\hline & \multirow[t]{3}{*}{3.0} & CT & 8 & 7 & 7 & 6 & 7 \\
\hline & & BW & 6 & 6 & 6 & 6 & 6 \\
\hline & & UT & 7 & 7 & 7 & 6 & 6.75 \\
\hline
\end{tabular}

$\mathrm{GSD}=$ greenhouse type solar dryer; $\mathrm{OSD}=$ open sun drying; $\mathrm{CT}=$ chemical treated; $\mathrm{BW}=$ boiling water; $\mathrm{UT}=$ untreated 
Table.2 Chlorophyll content, ascorbic acid, rehydration ratio of dried coriander leaves in room temperature storage

\begin{tabular}{|c|c|c|c|c|c|c|c|c|c|}
\hline \multirow{2}{*}{$\begin{array}{l}\text { Storage } \\
\text { time, } \\
\text { days }\end{array}$} & \multicolumn{3}{|c|}{$\begin{array}{c}\text { Chlorophyll content, } \mathrm{mg} / \mathrm{g} \\
\text { tissue }\end{array}$} & \multicolumn{3}{|c|}{ Ascorbic acid, mg/100g } & \multicolumn{3}{|c|}{ Rehydration ratio } \\
\hline & G1 & G2 & G3 & G1 & G2 & G3 & G1 & G2 & G3 \\
\hline $\mathbf{0}$ & 1.439 & 1.431 & 1.159 & 142.55 & 115.42 & 77.56 & 5.461 & 5.406 & 4.851 \\
\hline 15 & 1.377 & 1.362 & 1.131 & 137.7 & 111.2 & 75.276 & 5.449 & 5.387 & 4.842 \\
\hline 30 & 1.342 & 1.331 & 1.112 & 131.9 & 107.78 & 71.53 & 5.426 & 5.364 & 4.831 \\
\hline 45 & 1.304 & 1.284 & 1.081 & 129.087 & 103.457 & 69.459 & 5.401 & 5.345 & 4.815 \\
\hline 60 & 1.291 & 1.265 & 1.057 & 121.91 & 99.615 & 67.774 & 5.391 & 5.301 & 4.807 \\
\hline 75 & 1.275 & 1.241 & 0.997 & 119.431 & 96.096 & 63.81 & 5.377 & 5.284 & 4.802 \\
\hline 90 & 1.257 & 1.233 & 0.977 & 111.645 & 94.714 & 61.543 & 5.352 & 5.256 & 4.799 \\
\hline 105 & 1.201 & 1.192 & 0.962 & 107.931 & 90.234 & 59.872 & 5.324 & 5.244 & 4.795 \\
\hline 120 & 1.167 & 1.157 & 0.943 & 103.734 & 86.713 & 55.063 & 5.306 & 5.235 & 4.793 \\
\hline
\end{tabular}

Table.3 Mean sensory scores of sensory evaluation of the stored samples

\begin{tabular}{|c|c|c|c|c|c|c|}
\hline Name of the sample & Days & colour & Appearance & Taste & Flavour & Over all Acceptability \\
\hline G1 & 0 & 9 & 8 & 9 & 8 & $\mathbf{8 . 5}$ \\
\hline & 120 & 9 & 8 & 8 & 7 & $\mathbf{8 . 0}$ \\
\hline \multirow{2}{*}{ G2 } & 0 & 8 & 8 & 8 & 7 & $\mathbf{7 . 7 5}$ \\
\hline & 120 & 8 & 7 & 7 & 6 & $\mathbf{7 . 0}$ \\
\hline & 0 & 8 & 8 & 7 & 7 & $\mathbf{7 . 5}$ \\
\hline & $\mathbf{1 2 0}$ & $\mathbf{7}$ & $\mathbf{7}$ & $\mathbf{6}$ & $\mathbf{6}$ & $\mathbf{6 . 5}$ \\
\hline
\end{tabular}

Fig.1 Variation of chlorophyll content with storage period

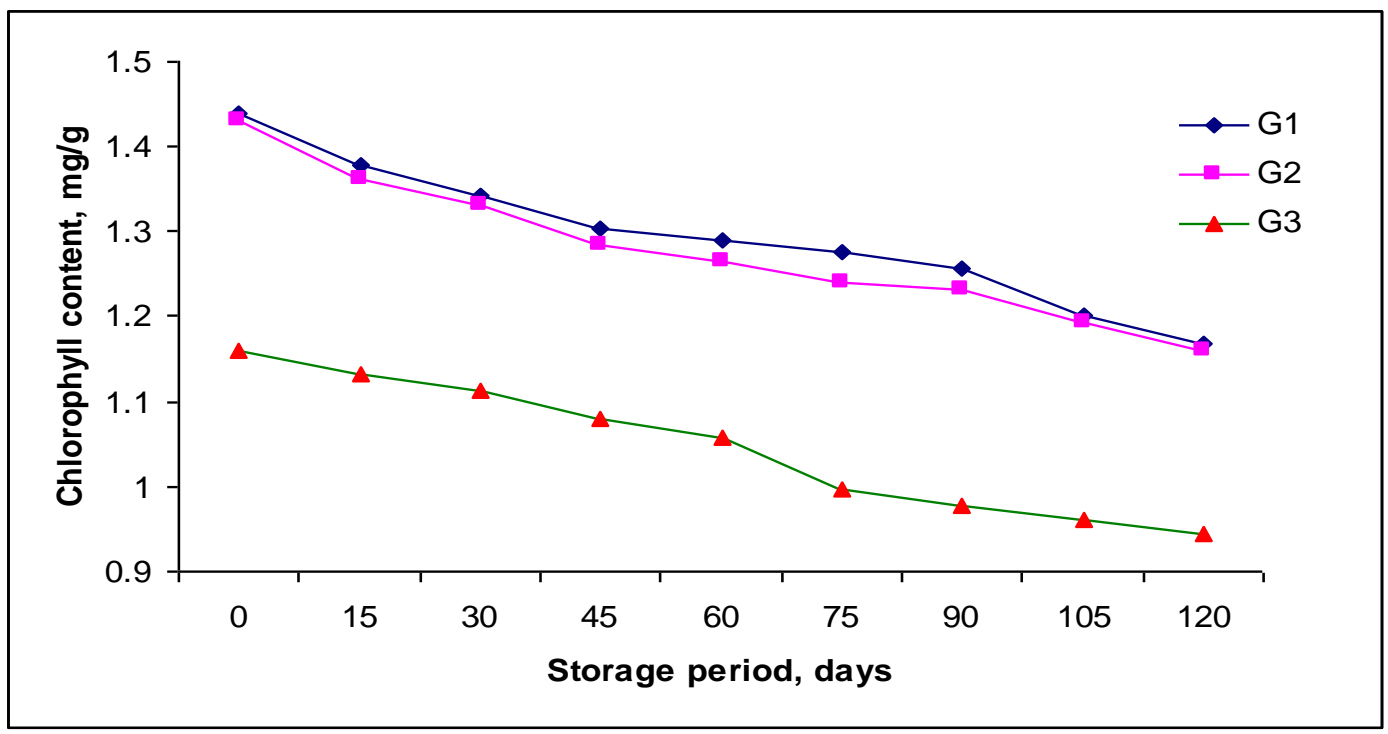


Fig.2 Variation of ascorbic acid with storage period

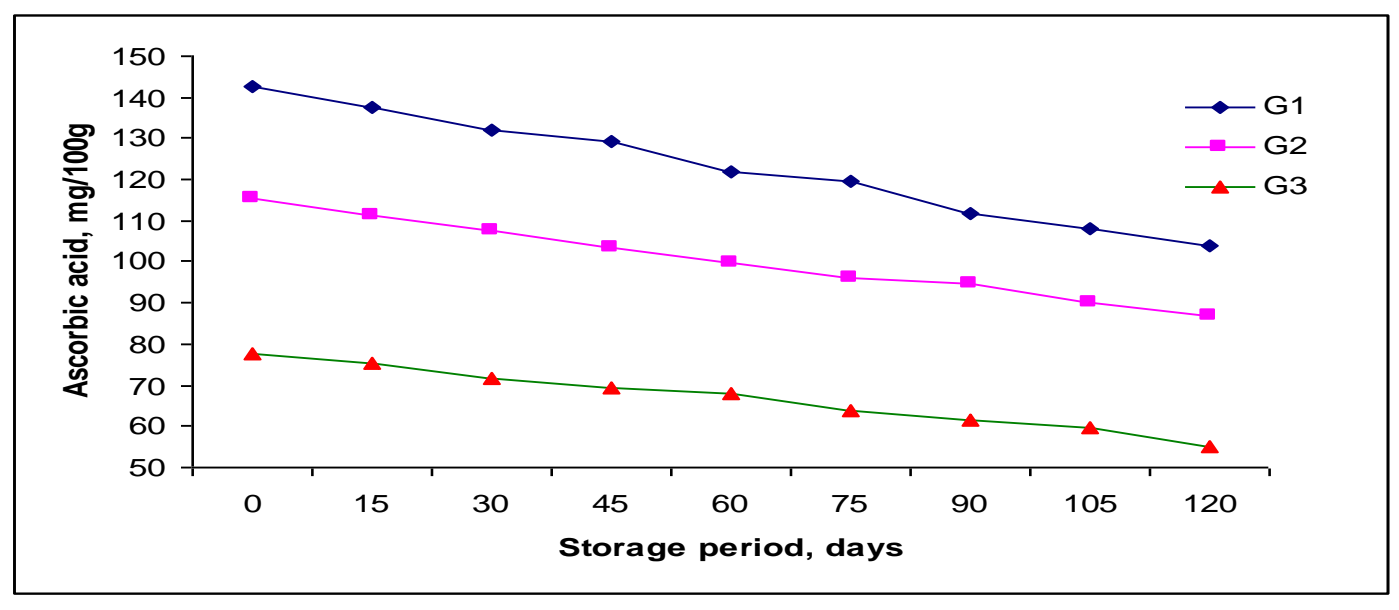

Fig.3 Variation of rehydration ratio with storage period

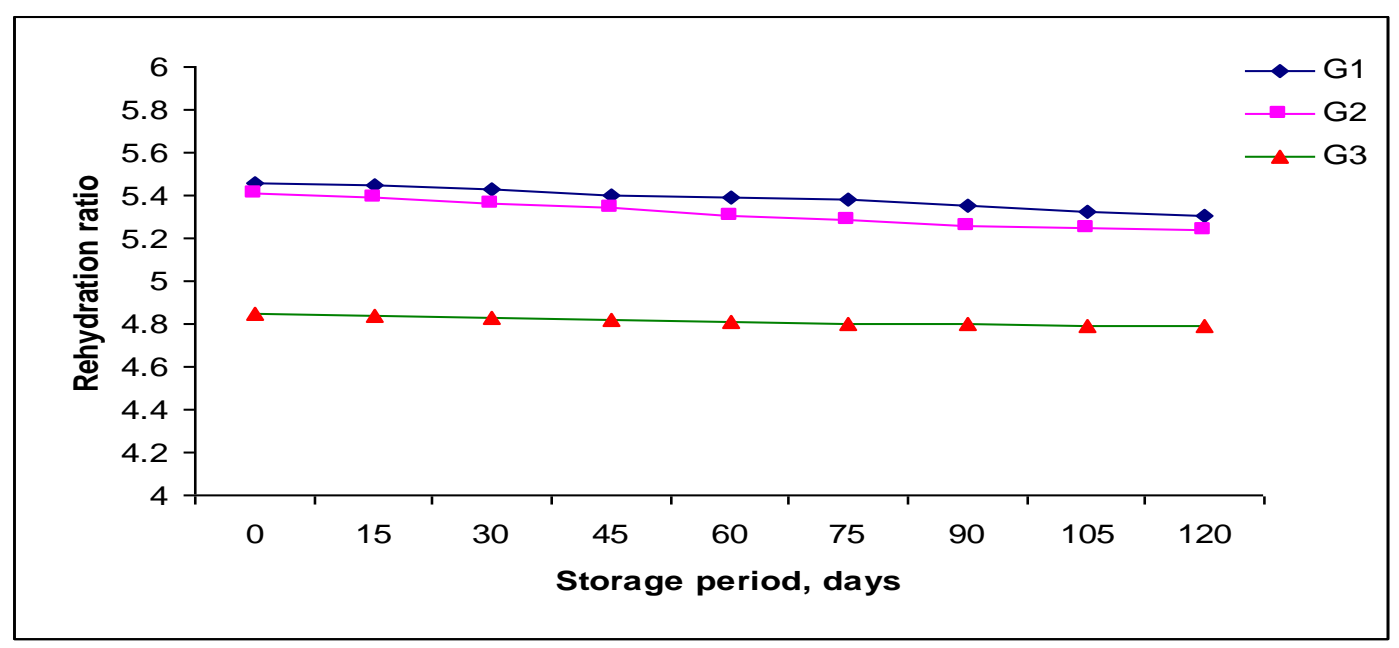

This may be due to the fact that drying by direct exposure to sun resulted in significant loss of pigments due to long time taken for drying, leading to more oxidation of carotene (Jayaraman et al., 1991). Lakshmi et al., (2000) reported that loss of $\beta$-carotene from green leafy vegetables after drying was found to be in the range of $24-40 \%$ in sun- dried leaves and $6-25 \%$ in cabinet dried leaves. The results of the present study are thus in agreement with the results of the above studies.

Fig. 2 showed the data and variation on ascorbic acid content $(\mathrm{mg} / 100 \mathrm{~g})$ at $0,15,30$,
45, 60, 75, 90, 105 and 120 days of storage. Ascorbic acid reduction after 120 days period was $27.22 \%, 24.87 \%$ and $29.0 \%$ for G1, G2 and G3 samples respectively. For G1, the reduction was from $142.55 \mathrm{mg} / 100 \mathrm{~g}$ (0 day) to $103.734 \mathrm{mg} / 100 \mathrm{~g}$ (120 days). For G2, the reduction was from $115.42 \mathrm{mg} / 100 \mathrm{~g}$ (0 day) to $86.713 \mathrm{mg} / 100 \mathrm{~g}$ (120 days). For G3, the reduction was from $77.56 \mathrm{mg} / 100 \mathrm{~g}$ (0 day) to $55.063 \mathrm{mg} / 100 \mathrm{~g}$ (120 days). The higher loss of ascorbic acid may be attributed to sensitivity of vitamin $\mathrm{C}$ at room temperature (30 - $40{ }^{0} \mathrm{C}$ ) during 4 months storage. At the start of storage, maximum ascorbic acid content $(142.55 \mathrm{mg} / 100 \mathrm{~g})$ was found for the 
samples dehydrated under GSD $\left(42^{\circ} \mathrm{C}\right)$ and minimum (77.56 mg/100g) was for the sample dehydrated under $\operatorname{OSD}\left(29^{\circ} \mathrm{C}\right)$. The less value of ascorbic acid content was observed for the samples which were exposed for longer drying time under open sun. This might be because of the increased activity of ascorbic acid oxidizing enzymes due to heating, which leads to destruction of ascorbic acid and leaching of vitamin C. It was also observed that although at higher temperature under GSD, the loss of ascorbic acid was less as the drying time was shorter. Direct exposure of coriander leaves to solar radiation was avoided as there was the provision of black shade net below the top glazing material in drying chamber, which reduces the loss of ascorbic acid in the samples placed under the dryer. Lakshmi et al (2000) reported that losses of ascorbic acid content from green leafy vegetables ranged from 69 to $85 \%$ due to sun drying $\left(35-40^{\circ} \mathrm{C}\right)$ and 51 to $63 \%$ due to cabinet drying $\left(60-70^{\circ} \mathrm{C}\right)$.

Fig. 3 showed the data and variation on rehydration ratio at $5 \mathrm{~min}$ of rehydration at 0 , $15,30,45,60,75,90,105$ and 120 days of storage. Reduction in rehydration ratio after 120 days was minimum for G3 (1.19\%) followed by $\mathrm{G} 1$ (2.84\%) and maximum for G2 (3.16\%). For G1, Rehydration ratio was 5.461 (0 day) which changed to 5.306 (120 days). For G2, Rehydration ratio was 5.406 (0 day) which changed to 5.235 (120 days) and for $\mathrm{G} 3$, rehydration ratio was 4.851 (0 day) which changed to 4.793 (120 days). The lower reduction in rehydration ratio over the 120 days storage period may be due to the lower change in the cellular structure during storage. The values of RR was high for the coriander dehydrated under GSD as drying methods affect the RR in rehydrated samples. McMinn and Magee (1997) reported similar results with RR and found concurrent increase in rehydration ratio with drying air temperature. Prolonged drying periods, with low temperature drying, induce increased thermal disruption of the cell organization, reducing the rehydration ratio and coefficient of rehydration.

\section{Changes in sensory qualities of coriander leaves during storage}

The data on organoleptic evaluation of dried coriander leaves as reported by the panel of 9 judges is presented in Table 3. The data on the sensory parameters revealed that as storage period advanced there was decrease in sensory quality parameters of dried coriander leaves. The rate of decrease in quality was less in all the three samples and it was slightly more in G3 as compared to G1 and G2 samples. The least decrease in overall acceptability was noticed in storage of G1 samples. After 120 days of storage, the samples G1 and G2 retained the highest sensory score in case of colour which were 9.0 and 8.0 respectively, while the sensory score of 7.0 was found in G3 sample. In all the samples, higher sensory scores for colour, appearance, taste, flavour and overall acceptability were indicative of their better suitability for dehydrated coriander leaves, after 120 days of storage. A slight difference of the sensory characteristics were observed in the selected samples after 120 days of storage. The best consumer preference in terms of overall acceptability after 120 days of storage was found in sample G1 (8.0) followed by G2 (7.0) and G3 (6.5). Hence, G1 sample was better on the basis of maximum score obtained for colour, appearance, taste and overall acceptability.

In conclusion on the basis of experimental results and data analysis, the following conclusions could be drawn:

The maximum value of sensory score of overall acceptability (8.5) for dehydrated coriander was obtained for chemical treated 
coriander leaves in the solution of $0.1 \%$ $\mathrm{MgCl}_{2}+0.1 \% \mathrm{NaHCO}_{3}+2 \% \mathrm{KMS}$ and with $2.5 \mathrm{~kg} / \mathrm{m}^{2}$ loading density under greenhouse type solar dryer, while minimum score (6.0) were found for open sun drying with boiling water treated samples at $2.5 \mathrm{~kg} / \mathrm{m}^{2}$ loading density.

Four months storage study of dehydrated coriander leaves revealed losses of $18.9 \%$ in chlorophyll content, $27.22 \%$ in ascorbic acid and $2.84 \%$ in rehydration ratio for the dehydrated product under greenhouse type solar dryer, as compared to the losses of 18.6 $\%$ in chlorophyll content, $29.0 \%$ in ascorbic acid and $1.91 \%$ in rehydration ratio under open sun drying.

Overall the greenhouse type solar dryer was found suitable for drying coriander leaves which can be safely stored for 4 months.

\section{References}

Ahmed, J., Shivare, U.S. and Singh, P. 2004. Colour kinetics and rheology of coriander leaf puree and storage characteristics of the paste. Journal of Food Chemistry. 84:605 - 611.

Anon. 1971. Guide for sensory evaluation of foods. (IS: 6273 I and II) BIS, New Delhi.

Arnon D. I. 1949. Plant Physiology.

Jayaraman K.S., Dasgupta, D. K. and Babu Rao, N. 1991. Quality characteristics of some vegetables dried under indirect sun drying. Indian Food Packer. 45(1):16-23.

Kaur, P., Kumar, A., Arora, S. and Ghuman, B. S. 2006. Quality of dried coriander leaves as affected by pretreatments and method of drying. European Food Research and Technology. 223: 189 194.

Lakshmi, B., Vimala, V. 2006. Nutritive value of dehydration green leafy vegetable powder. J. Food Sci. \& Tech. 37(5):465-471.

McMinn W. A. M., Magee, T. R. A. 1997. Physical characteristics of dehydrated potato - part I and II. Journal of Food Engineering. 33:37-55.

Pande, V. K., Philip, S. K., Sonune, A. V. 2000. Solar drying of coriander and methi leaves. Journal of Food Science and Technology. 37(6):592-595.

Ranganna, S. 1986. Handbook of analysis and quality control for fruits and vegetable products. Tata McGraw-Hill Publishing Ltd. New Delhi.

Singh, Sanjay Kumar, Pathak, P. K., Dwivedi, P. N. and Sahay, C. S. 2017. Drying characteristics of berseem in a solar dryer with supplemental heating system. Range Management and Agroforestry. 38(1): 143-146.

Tan, C. T., Francis, F. J. 1962. Effect of processing temperature on pigment and colour of spinach. Journal of Food Science. 27: 232.

\section{How to cite this article:}

Sanjay Kumar Singh, Samsher, B. R. Singh, R. S. Sengar and Pankaj Kumar 2020. Sensory Characteristics of Dehydrated Coriander Leaves under Greenhouse Type Solar Dryer and its Qualitative Evaluation during Storage. Int.J.Curr.Microbiol.App.Sci. 9(08): 1133-1142. doi: https://doi.org/10.20546/ijcmas.2020.908.125 